\title{
Cut, cut, cut
}

\section{WHY TO CUT?}

When bankers are openly pocketing many millions of pounds in bonuses, and when the wealth of the country remains obscenely concentrated in the hands of a tiny plutocracy, should we contemplate slashing public expenditure aimed at the common good? Unfortunately, egalitarian principles are unlikely to cut much ice with an incoming Tory government, nor yet with an improbable renascent Labour one. So, the answer is 'Because that's what the Treasury demands'.

\section{WHAT TO CUT?}

Here are three suggestions: elderly toenails, the NICE value-for-money threshold, and the crap.

By the first, I mean that basic services, podiatry for example, that preserve the daily quality of life of our most vulnerable, should be preserved as a priority, while high-cost, high-risk, high-tech interventions should be focused more discriminatingly to achieve maximum benefit. Take the case of a slightly fictionalised older patient of mine, admitted 3 months ago for a routine hip replacement. This was complicated by a perioperative myocardial infarct; angiography indicated severe multivessel disease and she was listed for a coronary bypass. She then developed an ischaemic toe, and was sent for revascularisation of the leg - prior to which she had another infarct. She finally made it to the CABG, which was in turn complicated by a sternal wound infection, pericardial effusion, pneumonia, and renal failure: after 4 weeks on intensive care she died. Of course in retrospect it is easy to say that someone, somewhere along the line should have said enough is enough, but who, and when? We should be re-examining our priorities. The cost of this patient's final 3 months of life would have funded, probably, the annual salary of two full-time chiropodists. Which would have given better value-formoney?

My second target is the NICE threshold for the adoption of new therapies or interventions. The current system is an open invitation to any drug company to price their innovative drug as high as they can get away with. As for the recent decision that the threshold should be raised (that is, a higher cost be accepted by the NHS for treatments in the terminal phase of life), the ethical rationale escapes me. By pandering to the special pleading of the chemotherapy lobby, we are denying treatments to those who have more to gain from life, in both quality and quantity, while condemning others to months of misery for dubious benefit. The other glaring problem with the NICE approach is that there is no extra money to follow the adoption of a newlyapproved treatment, so something else has to suffer - probably those poor old feet again.

Finally, as for the crap, by this I mean all those posts which have epithets such as 'czar(ina)', 'champion', 'coordinator', and 'advisor'; all initiatives that promise patients extra, but usually trivial, choice; all new primary care-based initiatives relating to obesity, exercise, and alcohol (the proper preserve of financial, educational and environmental agencies); all additions to the QOF; all booklets produced by the NHS and sent unsolicited in bulk to GPs' surgeries; the idle use of the words 'excellence', 'quality' and 'world-class' (although the latter should perhaps be spared as it can bring a burst of merriment into an otherwise dreary day); and finally, public consultations which promise to listen but refuse to hear.

\section{Dougal Jeffries}

DOI: 10.3399/bjgp10X483661

\section{'What to cut? ... elderly toenails ...'}

\section{NHS cuts and services: can we afford it?}

Although there are reassuring messages of protecting the NHS from cuts from both Gordon Brown and David Cameron there is an inevitability of reduced budgets that would be foolish to ignore. Politicians' pre-election promises hold little water and, as a profession, MPs are deft at delivering excuses for changes in direction. The UK budgetary imbalance is large and predicted as the largest in Europe. The IMF ${ }^{1}$ has identified the NHS is a major resource of savings for the UK economy and McKinseys, ${ }^{2}$ as management consultants to the NHS, have given their view on how this should be effected.

The NHS has received consistent budgetary increases since 2000. Much of this arose from a historical imbalance in UK health spending in terms of GDP compared with its EU neighbours, ${ }^{3}$ but even with consistent increases the UK still remains behind. However, the current UK economic figures are stark and apparent savings have to be made and the NHS is a major source. Whatever way any government this year distributes cuts across the public sector, health will suffer. Currently the English NHS budget is $£ 102$ billion (£120 billion for the UK). The Kings Fund predicts a worse-case scenario with cuts of $2 \%$ per annum. ${ }^{4}$ However, this relatively benign sounding reduction in funding needs to be offset. The same authors identify pressures on the NHS, just to stand still, in terms of quality and volume of activity. These pressures are identified as predominantly arising from a growing and ageing population: the over-75 population predicted to rise by $19 \%$ of current levels by 2017 with consequential increases in health demand inferred.

NHS spending has been under constant scrutiny for many decades and the spending regularly compared against the quality and volume of delivery of health care. Many different models of care 
provision have been developed to improve outcomes in terms of cost and clinical care. ${ }^{5}$ Overall, including the current vogue for the polysystem model, their improved effectiveness and economy still needs to be evaluated to provide evidence of any benefits. Non-clinical NHS expenditure, such as administration and IT may provide more room for savings. ${ }^{6}$ Similarly increased privatisation of services is very much in vogue at the moment. However, the longest standing example of this model of commissioning, contract hospital cleaning, provides evidence of neither cost reduction nor quality improvements. ${ }^{7,8}$

Other models for the delivery of health care, both on micro and macro levels will no doubt be presented over the coming weeks and indeed years to achieve the combined goals of volume and quality of care within reducing budgets. Many will ably and capably argue their case and deliver different options. It would be naive to imagine that those with vested interests will dispassionately view the overall national need. It is reasonable to expect rational and often emotive arguments clamouring for a particular model of service redesign, or investment in a particular geographical area or clinical specialty, put forward to justify prioritisation and protection from cuts and furthermore attempt to justify additional investments.

In the ever ongoing analysis of health spending and efficiency there is not much room for further cuts in primary care. Prescribing, skill mix, and transfer of chronic disease management have undergone considerable change and supervision with a specific target to achieve cost savings, ${ }^{9}$ yet there are now only diminishing potential returns still available. Work on reducing referrals and creating care pathways will have at best only a limited local effect on cost reductions. Primary care has the skills and ability to take on more secondary care work but would require an investment in space and personnel that will not be on the government's agenda for many years. Secondary care itself may cut volumes of elective care but the potential saving is limited because the cost of terminating employment contracts may exceed potential savings. Technology investment is being delayed with announcements on the withdrawal from further large scale NPfIT funding, ${ }^{5}$ but disinvestment runs the longer term risk that the health service becomes more expensive to run as the introduction of newer cheaper technologies are delayed. New capital expenditure will inevitably be delayed and healthcare workers and patients will somehow have to make do.

Importantly, general practice must ensure it does not miss out on the debate. Inasmuch as primary care is inevitably set for change within an ever-changing $\mathrm{NHS}$, GPs must be at the forefront of discussions to make sure that those features we most prize are not lost in a new system which has been constructed by others. Leadership is one of the most crucial attributes the NHS lacks and is most needed at this difficult time. ${ }^{10}$ GPs must position themselves to be among the leaders and be the lead architects at both a local and national level.

\section{Nigel de Kare-Silver}

\section{Acknowledgements}

I dedicate this article to the late Kieran Sweeney. I was on the RCGP Leadership course 2008-2009 which he led and he was an absolute inspiration.

\section{REFERENCES}

1 International Monetary Fund. United Kingdom: 2009 Article IV Consultation-Staff Report; Staff Statement; Public Information Notice on the Executive Board Discussion; and Statement by the Executive Director for United Kingdom. IMF Country Report No. 09/212. http://www.imf.org/external/pubs/ft/scr/2009/cr09212. pdf (accessed 28 Jan 2010).

2 Civitas. McKinsey's prescription for the NHS. http://www.civitas.org.uk/wordpress/2009/09/03/mcki nseys-prescription-for-the-nhs (accessed 28 Jan 2010).

3 Emmerson C, Frayn F, Goodman A. How much would it cost to increase UK health spending to the European Union average? Briefing Note No. 21 . The Institute for Fiscal Studies, 2002: DOI: 10.1920/bn.ifs.2002.0021.

4 Appleby J, Crawford R, Emerson, C. How cold will it be? Prospects for NHS funding 2011-2017. London: The King's Fund, 2008.

5. Department of Health. Health reform in England: update and next steps.

http://www.dh.gov.uk/en/Publicationsandstatistics/Pub lications/PublicationsPolicyAndGuidance/DH_412472 3 (accessed 3 Feb 2010).

6 Heath N. Deep NHS IT cuts could hurt frontline healthcare, doctors warn.

http://www.silicon.com/management/publicsector/2009/12/07/deep-nhs-it-cuts-could-hurtfrontline-healthcare-doctors-warn-39694447/ (accessed 28 Jan 2010).

7 Auditor General for Scotland. Hospital Cleaning. Executive Summary. Edinburgh: Auditor General, 2003.

8 Bowcott O. Hospital regulators under fire for failures at Essex hospital. Guardian: 27 Nov 2009. http://www.guardian.co.uk/society/2009/nov/27/hospit al-regulators-failures-essex-hospital (accessed $26 \mathrm{Jan}$ 2010).

9. Department of Health. The NHS Plan. A plan for investment. A plan for reform.

http://www.dh.gov.uk/en/Publicationsandstatistics/Pub lications/PublicationsPolicyandGuidance/DH_4002960 (accessed 3 Feb 2010).

10. The NHS Confederation. Dealing with the downturn. http://www.nhsconfed.org/Publications/Documents/D ealing_with_the_downturn.pdf (accessed 28 Jan 2010).

DOI: 10.3399/bjgp10X483670 